https://doi.org/10.15407/scine18.01.029

KREMEN, V. G. 1, 2 (https://orcid.org/0000-0001-5459-1318),

HRYNEVYCH, L. M. ${ }^{3}$ (https://orcid.org/0000-0002-5818-8259),

LUGOVYI, V. I. 1, 4 (https://orcid.org/0000-0003-1650-066X),

and TALANOVA, Z. V. ${ }^{4,5}$ (https://orcid.org/0000-0003-4007-2677)

'Presidium of National Academy of Educational Sciences of Ukraine,

52-A, Sichovykh Striltsiv St., Kyiv, 04053, Ukraine,

+380 44481 3701, president@naps.gov.ua

2Presidium of National Academy of Sciences of Ukraine,

54, Volodymyrska St., Kyiv, 01030, Ukraine,

+380 442396444, prez@nas.gov.ua

${ }^{3}$ Borys Grinchenko Kyiv University,

18/2, Bulvarno-Kudriavska St., Kyiv, 04053, Ukraine,

+380 44272 1902, kubg@kubg.edu.ua

${ }^{4}$ Institute of Higher Education of National Academy of Educational Sciences of Ukraine,

9, Bastionna St., Kyiv, 01014, Ukraine,

+380 44286 6804, ihed@ukr.net

${ }^{5}$ National Erasmus+ Office in Ukraine,

9. Bastionna St., Kyiv, 01014, Ukraine,

+38044286 6668, office@erasmusplus.org.ua

\title{
QUALITY OF EDUCATION AND
}

INNOVATION-DRIVEN DEVELOPMENT:

THE NEW UKRAINIAN SCHOOL REFORM IN THE CONTEXT OF GLOBAL TRENDS

Introduction. Accelerating human progress is a result of the growing role of innovations. This requires the development of an innovative person as an effective actor of their implementation and support. Primary, and secondary education is very important factor for this. The New Ukrainian School (NUS) reform that has been being implemented since 2016 shall adequately meet current challenges and trends.

Problem Statement. To this end, it is very important to identify the key intra-system and contextual factors influencing the quality of school education, first of all in reading, mathematics, and natural sciences, in terms of the development of an innovative person.

Purpose. The purpose of this research is to determine the endogenous (internal) and exogenous (external) factors that effectively influence the educational quality, in order to optimize the NUS implementation in the present-day conditions.

Materials and Methods. Multifactor system analysis (in particular statistical, correlation, and comparative techniques) of big global databases on human development, international assessment of the quality of primary and basic secondary education, development of world research and university spheres and features of the NUS implementation in Ukraine.

Citation: Kremen, V. G., Hrynevych, L. M., Lugovyi, V. I., and Talanova, Z. V. (2022). Quality of Education and Innovation-Driven Development: the New Ukrainian School Reform in the Context of Global Trends. Sci. innov., 18(1), 29-43. https://doi.org/10.15407/scine18.01.029 
Results. The probable global connections between the quality of school education and the factors of internal educational and external contextual impact on the educational quality have been identified. Among the considered nine factors effecting the quality of student education in reading, mathematics, and science, the most influential (resonant) and stable are the endogenous ones, namely, the mean years of schooling, and the share of $R \mathcal{E} \mathcal{F}$ expenditure in GDP, with the latter having a greater impact. The recommendations for improving the efficiency of the NUS have been given.

Conclusions. The effectiveness of school education reform, in particular, NUS, may be raised by taking into account the deterministic effect of endogenous and exogenous factors on the quality of education.

Keywords: innovative person, quality of education, endogenous and exogenous factors, and the New Ukrainian School.

In recent years, new systematic data on the quality of primary and basic secondary education in the world and in some countries have been published. These are, first of all, the results of the Program for International Student Assessment (PISA 2018) for 15-year-old students in reading, mathematics, and science with a total coverage of 600 thousand students from 79 countries, including Ukraine, for the first time [1-4]; Trends in International Mathematics and Science Study (TIMSS 2019, more than 580 thousand students from 64 countries, including 54 countries for students of $4^{\text {th }}$ grade and 39 countries for students of $8^{\text {th }}$ grade, excluding Ukraine) [5, 6] and Progress in Internatinal Reading Literacy Study (PIRLS 2016, for 310 thousand students of $4^{\text {th }}$ grade from 50 countries, excluding Ukraine) [7,8].

PISA is administered by the Organization for Economic Cooperation and Development (OECD) [9]. Since 2000, three-year period evaluations have been conducted seven times. Each time, almost all OECD members join them (in 2018, all 37 member countries and 8 associate members) $[1-3,9]$. TIMSS and PIRLS are implemented under the auspices of the International Association for the Evaluation of Educational Achievement (IEA) with the assistance of partners, including the International Study Center (ISC) of Boston College $[5-8,10]$. According to Carnegie's classification, the Boston College belongs to the group of 131 U.S. universities with the highest research activity [11]. Since 1995, TIMSS four-year period assessment has been conducted seven times, with Ukraine taking part twice (in 2007, for students of $4^{\text {th }}$ and $8^{\text {th }}$ grades and in 2011, for students of $8^{\text {th }}$ grades) $[5,6,10]$. PIRLS that complements TIMSS was introduced in 2001 and is held every five years. The last time was in 2016, so the next evaluation is planned for 2021. Ukraine has never joined this program $[7,8]$.

Another relevant source of global data according to the United Nations Development Program (UNDP) with a 30-year history is the latest Human Development Report 2020 (HDR-2020) that covers 189 countries. The report provides human development indices and components in relation to life expectancy, education, and income, as well as other important socio-economic indicators, which in particular determine the level of innovation-driven development [4]. Ukraine is consistently represented in the report. Its Human Development Index (HDI) is primarily backed by relatively high education indicators [4, 12-15].

In addition, there has been published the annual data of the Shanghai Academic Ranking of World Universities 2020 (ARWU 2020) for the general (60 countries) and sectoral (54 academic subjects, 90 countries) universities of the world (the top 500) and the sub-world (501-1000) classes (Ukraine is not ranked) [16-18]. The relatively new concepts of the world class and the subworld class (candidates for the world class) universities have been established and used globally starting with 2007-2009, but not yet fully understood in Ukraine as factor influencing the formation of innovative people, innovative society, and innovation-driven economy [19-21]. According to this rating that is published since 2003, National Taras Shevchenko University of Kyiv has been the only Ukrainian university that once (in 
2017), in the field of mathematics was included in the last rating group (401-500), i.e. was internationally recognized as a world-class university in this subject area $[16,21]$. ARWU, as compared with two other government-recognized international rankings (Times and QS), has become more widespread because of its objectivity and the best fit of its criteria and indicators to the principles of research and innovation-driven progress [16-22].

Thus, the world community accumulates, expands, and updates the heuristic array of systemic global and, most importantly, reliable relevant data that characterize modern human development and reflect its growing focus on innovation, especially in education. These and other empirical data require a comprehensive theoretical and methodological understanding. After all, they make it possible not only to find out, but also to explain the deep connections of various parameters of development with the quality of modern education and the degree of its compliance with leading trends.

In particular, the data have shown that the development of education in Ukraine has not always corresponded to the global challenges and trends. In 2010, the UNDP concept of human development (after 20 years of successful operation of the program) changed significantly its educational component of HDI. The years of schooling factor is preferred over the primary literacy of the population and the education coverage, which have lost its global relevance [14, 15]. However, in 2010, contrary to reasonable objections, in particular from NAES of Ukraine (for example, in the speech of Vasyl Kremen at the parliamentary hearings on June 9, 2010 [23]), at the finish line, at the insistence of the Verkhovna Rada of Ukraine, Ukraine stopped the transition to a 12-year period of complete general secondary education [24]. The mentioned transition started in 2001 in accordance with the Law of Ukraine on the General Secondary Education (1999) [25], was confirmed by the National Doctrine of the Education Development in 2002 [26], which has been still relevant, and should aim at improving the quality of school education. After all, the 12-year school has been already dominant in the world, especially in Europe, and allows better implementation of the principle of child-centeredness in education and the formation of innovative person capable of continuous learning and acquiring new competencies in a knowledge society [26-29].

This has adversely affected the study of basic school subjects (language, mathematics, and natural sciences). According to the results of TIMSS 2011, the eighth-graders of Ukraine ranked $19^{\text {th }}$ in mathematics and $18^{\text {th }}$ in natural sciences among 42 countries [10], and according to PISA 2018, the 15-year-old Ukrainian students in these subjects were $44^{\text {th }}$ and $39^{\text {th }}$ respectively, among 79 countries [1].

In 2012-2014, the authors of this research took part in the transition of Ukraine to a new quality of education mainly by introducing quality assurance systems in the educational sphere in different educational levels without extending the years of schooling, starting with the Bologna process in higher education [30, 31]. This was important for the integration of the Ukrainian education sphere into the European Higher Education Area that was formed since 1999, the European Vocational Education and Training Area (under the Copenhagen process, since 2002) [32], and later to the European Education Area that was initiated in 2017 and is scheduled to be completed in 2025 [33]. Therefore, the law on the Higher Education (2014), the first one among the new generation of educational laws, contains a separate section on the quality assurance in education [31]. Since then, the presence of such a special section in the subsequent educational laws has become the norm [34-36]. However, this is not enough to achieve the quality of education.

In 2015-2016, the National Academy of Educational Sciences of Ukraine, the respective Committee of the Verkhovna Rada of Ukraine and the Ministry of Education and Science of Ukraine were elaborating the concept of the second attempt to start a systematic and consistent transition to 12-year school education structured into the pri- 
mary, the basic, and the field-specific secondary education in accordance with the International Standard Classification of Education 2011 (ISCED 2011) [37-43]. Approved by the government in 2016, the Concept of the New Ukrainian School (NUS) [44] is designed to solve this problem, embodied in the Law of Ukraine on Education (2017) [34] and enshrined in the Law of Ukraine on Complete General Secondary Education (2020) [35]. In 2017-2020, the implementation of NUS has highlighted new threats and caused concern, in particular regarding the lag in its implementation, the study of natural sciences and mathematics and more $[3,44-50]$. In addition, the opponents of the 12-year-old schooling again contest the appropriateness of this conception, contrary to global and European trends, and now the generally accepted tradition [51]. Therefore, the completion of the implementation of 12-year complete general secondary education in 2029 requires reliable, scientifically sound support and protection.

More than 15-year unjustified delay in the implementation of the 12-year school has had an adverse impact on the growth rate of Ukraine's HDI as compared with other countries (Table 1).

At the same time, compensating for the shortness of complete general secondary education by excessively disproportionate expansion of access to higher education (Table 2) although has caused a slight increase in the index of years of schooling as a whole, but adversely affected the quality of both secondary and higher education. As a result, university principals have been complaining about the quality of entrants' education.

Table 1. Trends in HDI in 2000-2019

\begin{tabular}{|l|c|c|c|c|}
\hline \multirow{2}{*}{ Country } & \multicolumn{3}{|c|}{ HDI } & HDI average annual \\
\cline { 2 - 4 } & 2000 & 2010 & 2019 & $\begin{array}{c}\text { growth rate } \\
\text { in 2000-2010 to that } \\
\text { in 2010-2019, times }\end{array}$ \\
\hline $\begin{array}{l}\text { Ukraine } \\
\text { 189 world } \\
\text { countries } \\
\text { OECD }\end{array}$ & 0.694 & 0.755 & 0.779 & 2.3 \\
\hline
\end{tabular}

Source: prepared by the authors based on [4].
Moreover, among the consequences of such an imbalance in education there was, in particular, the persistent lack of world and even sub-world class universities in Ukraine because of too wide and scattered network of higher education institutions, under conditions of a relative underfunding of primary and secondary education and an overfunding of higher education [21, 40, 42, 50, 52].

Table 3 shows the importance of HDI educational components for Ukraine.

Table 3 shows that Ukraine continues to lag significantly behind the OECD and even the world as a whole in terms of life expectancy and per capita income. However, in terms of educational parameters, the country is ahead of the world and historically not far behind the OECD. At the same time, for the above reasons, from 2010 to 2019, the gap between OECD and Ukraine increased in terms of years of schooling, but thanks to the NUS introduction, it is expected to decrease.

Although NUS and relevant laws regulate the system of progressive measures to improve school education [34-36, 44, 49, 50], nevertheless, given the need for permanent monitoring of the NUS implementation [3], it is important to continue the search for reliable global factors, both endogenous and exogenous, of imperative impact on the quality of education.

In order to outline the list of potential factors and to further determine their current impact on the quality of education, the Human Development

\section{Table 2. The General Coverage of the Population with Education of Different Levels Normalized to the Appropriate Age Group}

\begin{tabular}{|c|c|c|c|c|c|}
\hline \multirow{2}{*}{ Country } & \multicolumn{4}{|c|}{$\begin{array}{l}\text { Coverage with education, } \\
\text { by level, in } 2017^{1}, \%\end{array}$} & \multirow{2}{*}{$\begin{array}{l}\text { The ratio } \\
\text { of the coverage } \\
\text { with higher and } \\
\text { secondary } \\
\text { education, times }\end{array}$} \\
\hline & $\begin{array}{l}\text { Early- } \\
\text { years }\end{array}$ & Primary & $\begin{array}{l}\text { Secon- } \\
\text { dary }\end{array}$ & Higher & \\
\hline Ukraine & 84 & 100 & 97 & 83 & 0.86 \\
\hline $\begin{array}{l}189 \text { world } \\
\text { countries }\end{array}$ & 50 & 105 & 79 & 36 & 0.46 \\
\hline OECD & 79 & 102 & 105 & 68 & 0.65 \\
\hline
\end{tabular}

${ }^{1}$ The latest available data for $2012-2017$.

Source: : prepared by the authors on the basis of [12]. 
Report indicators that are typical and accessible to all countries are taken as a basis. First of all, these are the components of synthetic HDI, namely: life expectancy, expected years of schooling, mean years of schooling, and income per capita. These characteristics of human development are supplemented by others that are based on recent and previous reports: the share of budget expenditure on education in GDP, the teacher-pupil ratio in primary school, and the share of $R \& D$ in GDP [4, 12-15]. Given the contribution of education to innovation and at the same time the competitiveness of human progress, such global factors as the presence of world and sub-world class universities in the interpretation of ARWU have been included as well [16-18, 21].

Some (six) of these factors, of course, are immanent to the educational sphere, i.e. endogenous to it. On the other hand, the other three (life expectancy, income per capita, and share of $R \& D$ in GDP) are exogenous, i.e. those that form the context of the operation and development of education. Definitions of the seven listed factors (except for the world and sub-world class universities) are given in the terminological explanations in each human development report [4,12-15].

In its reports, UNDP also regularly provides data on self-assessment of the quality of education in countries, the education quality satisfaction percentage $[12,53]$. This subjective indicator, as shown in [53], differs significantly from the objective indicators, for example, the PISA results. Therefore, this research uses the objec- tive indicators of PISA, TIMSS, and PIPLS for different aggregates (groups) of countries as indicators of the quality of education.

The most representative are the data of the latest PISA 2018 survey that involved 79 countries/territories, including Ukraine [1-3]. They have been used as a basis for characterizing the quality of education (learning outcomes, student achievement). Given that the Human Development Report does not contain relevant data for Kosovo, Macau and Taiwan, we have considered the 76 other PISA 2018 countries, more than half of which are OECD members (37) and associate members (8) [9]. These 76 countries are ranked from 1 to 121 (out of 189) in terms of HDI in HDR 2020 [4]. Similar surveys TIMSS 2019 and PIRLS $2016[5-8,10]$ covering significantly fewer countries have been analyzed additionally.

Although the results of PISA 2018, TIMSS 2019, and PIRLS 2016 have been widely analyzed $[1-8,10,54]$, such analysis as in this research has not been done yet.

To determine the relationship between the quality of education and the outlined factors of human development, the Pearson correlation coefficients $\left(\mathrm{K}_{\text {pears }}\right)$ have been calculated in Excel and interpreted. The relationship is considered strong if the correlation coefficient exceeds 0.60 , and very strong if it exceeds 0.90 . The critical value of the correlation coefficient $\left(K_{c r}\right)$ is determined for the significance level $p=0.05$ (that is common for the socio-humanitarian sciences [55]), according to the number of compared parameters $N$ in each case [56].

Table 3. The Role of Various Components of the Human Development Index in Ukraine, the World and the Organization for Economic Cooperation and Development in 2010 and 2019

\begin{tabular}{|l|c|c|c|c|c|c|c|c|}
\hline \multirow{2}{*}{\multicolumn{1}{c|}{ Country }} & \multicolumn{2}{|c|}{ Life expectancy, years } & \multicolumn{2}{c|}{ Years of schooling, years } & \multicolumn{2}{c|}{$\begin{array}{c}\text { Expected years } \\
\text { of schooling, years }\end{array}$} & \multicolumn{2}{c|}{$\begin{array}{c}\text { Gross national income } \\
\text { per capita, PPP, USD }\end{array}$} \\
\cline { 2 - 9 } & 2010 & 2019 & 2010 & 2019 & 2010 & 2019 & 2010 & 2019 \\
\hline Ukraine & 68.6 & 72.1 & 11.3 & 11.4 & 14.6 & 15.1 & 6.5 thou & 13.2 thou \\
189 world countries & 69.3 & 72.8 & 7.4 & 8.5 & 12.3 & 12.7 & 10.6 thou & 16.7 thou \\
OECD & 80.3 & 80.4 & 11.4 & 12.0 & 15.9 & 16.3 & 37.1 thou & 44.4 thou \\
OECD/Ukraine, times & 1.17 & 1.12 & 1.01 & 1.05 & 1.09 & 1.08 & 5.7 & 3.4 \\
\hline
\end{tabular}

Note: PPP is purchasing power parity

Source: prepared by the authors on the basis of [4]. 


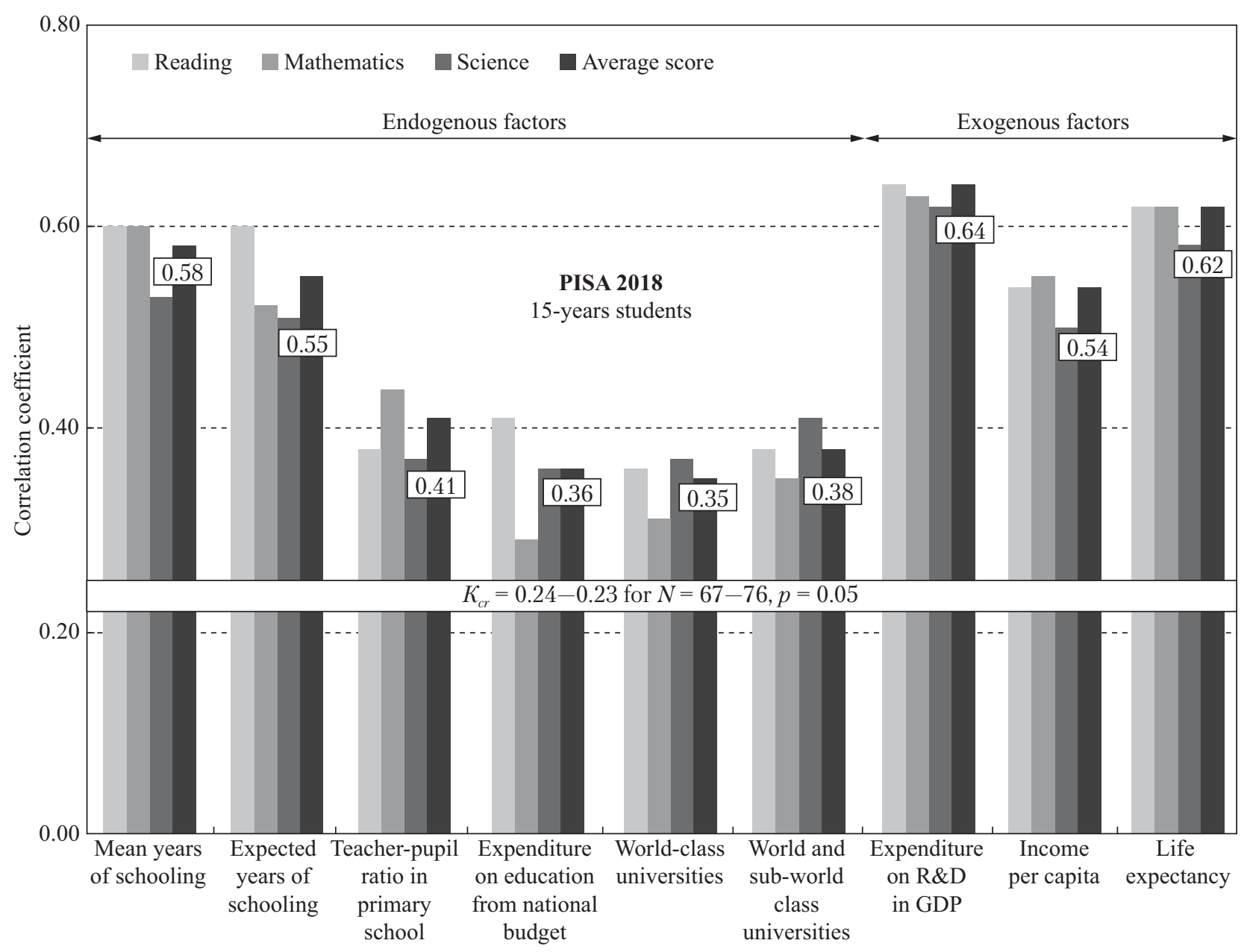

Fig. 1. The correlation (the Pearson coefficient) between the student achievement according to PISA 2018 and the endogenous and exogenous factors that affect the quality of education in different ways Source: calculated by the authors on the basis of $[1,2,4,12,13,17]$.

The calculated correlation factors based on the PISA 2018 data on achievement in reading, mathematics, science ( $N=76$ and 75 , as no data on reading are available for Spain) have shown a very strong interdisciplinary correlation $\left(\mathrm{K}_{\text {pears }}\right.$ ranges within $0.95-0.97)$. This allows us to use the average score for the three subjects while doing comparisons for the purposes of this research (the correlation between the average scores and scores for individual subjects remained very strong in the range of $0.98-0.99$ ).

Fig. 1 shows the values of the Pearson correlation coefficient of student achievement scores in reading, mathematics, and science and the ave- rage for the three subjects, on the one hand, and, on the other hand, all other endogenous and exogenous factors influencing the quality of education for which systemic global reliable data are available, namely:

\section{a) the endogenous factors}

- mean years of schooling (average number of years of education received by people ages 25 and older, converted from educational attainment levels using official durations of each level);

- expected years of schooling (number of years of schooling that a child of school entrance age can expect to receive if prevailing patterns of 
age-specific enrolment rates persist throughout the child's life;

- teacher-pupil ratio in primary school;

- the share of expenditure on education from national budget in GDP, \%;

- world-class universities (number of such universities in the country);

- world and sub-world class universities (number of such universities in the country);

b) the exogenous factors

- the share of expenditure on R\&D in GDP, \%;

- income per capita (gross national income per capita at purchasing power parity, in USD);

- life expectancy at birth (years).

Insofar as in all $36(4 \times 9)$ correlation pairs, the data are available for at least 67 out of 76 countries, the critical value of the Pearson correlation coefficient for the significance level $p=0.05$ does not exceed 0.24 [56]. Therefore, all correlations are positive and probable, but have different values (see Fig. 1).

Regarding the endogenous factors, the most important correlations for them are related to the years of schooling. Moreover, in the case of the mean years of schooling, the correlation with student achievement is close to the strong one. Approximately the same, but not strong, are the correlations between the student achievement and the teacher-pupil ratio in primary school, the share of expenditure on education from national budget in GDP, the presence of world-class universities and world and sub-world class universities. The weak correlations in the last two cases may be explained by a certain remoteness of the elite flagship universities from the mass primary and secondary school. However, in any case, all these endogenous factors are positively relevant, although the priority factors are years of schooling.

With regard to the exogenous factors, the correlation for income per capita is approximately as strong as for the endogenous factor of expected years of schooling, and the correlation for life expectancy is approximately as strong as that for the endogenous factor of mean years of schooling. At the same time, the most resonant factor among both exogenous and endogenous factors is the share of expenditure on R\&D in GDP. This is the only factor that for all the subjects strongly (!) correlates with student achievement in reading, mathematics, and science.

This result has shown that the general research and innovation context of the country, if strongly supported by resources, has a significant (if not the main) impact on the student achievement in reading, mathematics, and science. This is explained, to a certain extent, by the pedagogical law of the correlation between complexity and independence in education, as formulated in the National Academy of Educational Sciences of Ukraine, according to which the level of mastering the subject directly depends on the level of independence [57]. The independence is driven by motivation, interest, and enthusiasm. Thus, an attractive, popularized, well-developed, advanced, and respectful R\&D sector and, as a consequence, an innovation-driven economy, encourage students to master mentioned subjects. Conversely, a degraded, poor, resourcebleeding $R \& D$ sector hence and a raw materials, low-income, low-technology economy with respective labor market discourage students from learning the subjects that are necessary for innovation-driven progress. After all, the quality of education is always based on advanced science not only in classrooms, but also in a broad social context, including out-of-school education, etc. [52].

These conclusions have been largely confirmed by analyzing the results of TIMSS 2019 and PIRLS 2016 surveys, albeit for fewer countries and with lower coverage of students (Figs. 2, 3). To ensure the consistent use of TIMSS data, the data for Pakistan and Taiwan are excluded, and the averaged data for Northern Ireland and England are taken as data for the United Kingdom. In the case of PIRLS, the data for Macau and Taiwan are excluded and the data for Northern Ireland and England, as well as for the Flemish and the French parts of Belgium are averaged.

Fig. 2 shows the correlation coefficients of the relevant factors and achievement of the $8^{\text {th }}$ grade students in mathematics and science for TIMSS 2019. 


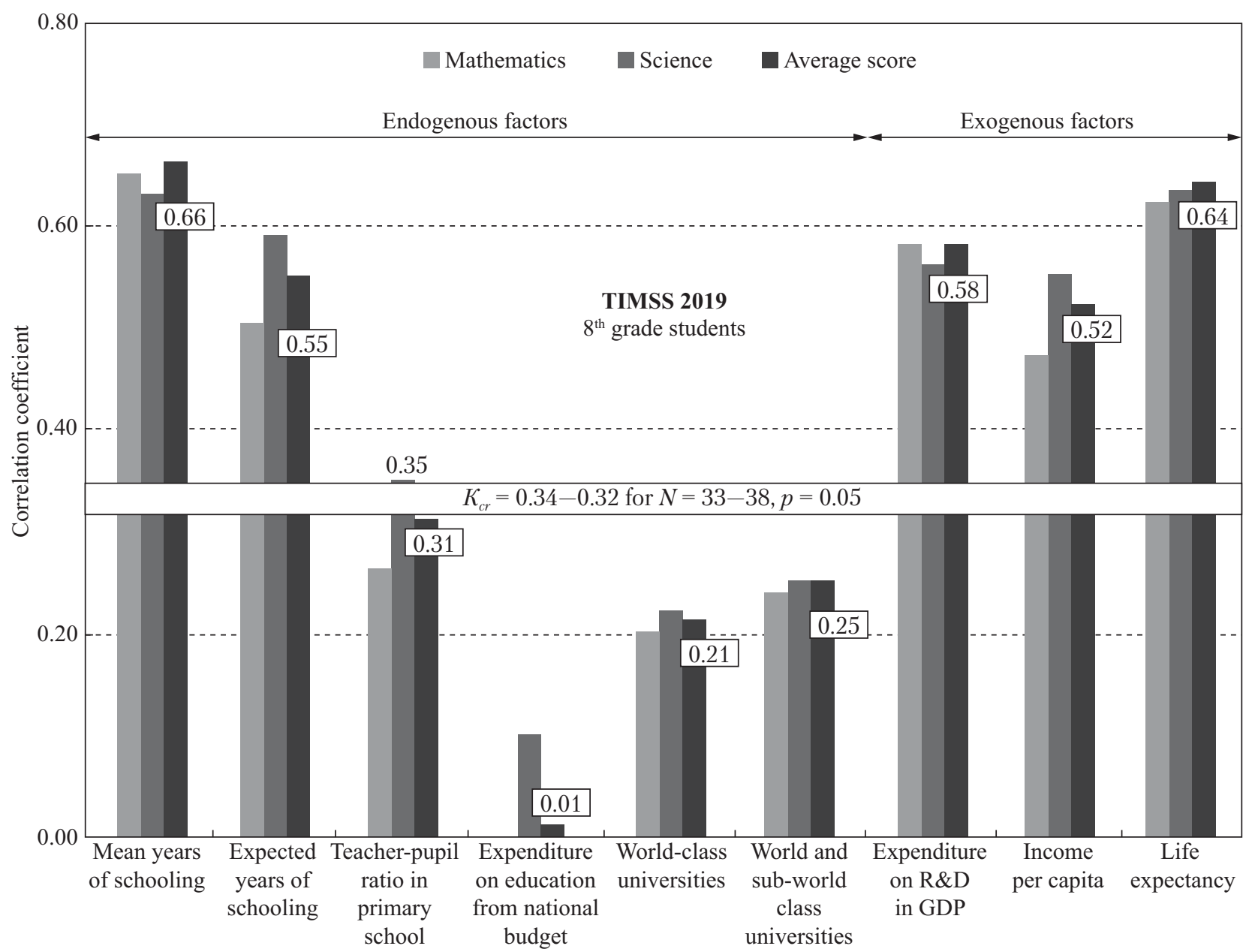

Fig. 2. The correlation (the Pearson coefficient) between the student achievement according to TIMSS 2019 and the endogenous and exogenous factors that affect the quality of education in different ways Source: calculated by the authors on the basis of $[4,5,12,13,17]$.

Fig. 3 shows that the distribution of correlation values by factors is similar to the distributions shown in Figs. 1, 2. The group of endogenous factors is led by mean years of schooling (strong correlation for all subjects, especially for reading) and expected years of schooling. At the same time, the role of teacher-pupil ratio increases significantly for the $4^{\text {th }}$ graders. However, the number of world and sub-world class universities and especially the share of expenditure on education from national budget in GDP do not have probable values. Among the exogenous factors, life expectancy and the share of expenditure on $R \& D$ in GDP remain the leaders.
Figs. $1-3$ also show that all the correlations are stable, i.e. such that do not lose probability, are mean and expected years of schooling (endogenous factors) and the exogenous factors.

Thus, the above-mentioned correlation analysis based on statistically significant data samples has shown that the length of schooling, which corresponds to the progressive norms, and appropriate support of R\&D and science most significantly contribute to the quality of school education. Therefore, the adequate duration of schooling as foreseen in the NUS ensures a reliable basis for the implementation of the global trend towards lifelong learning in Ukraine. In particular, the National 


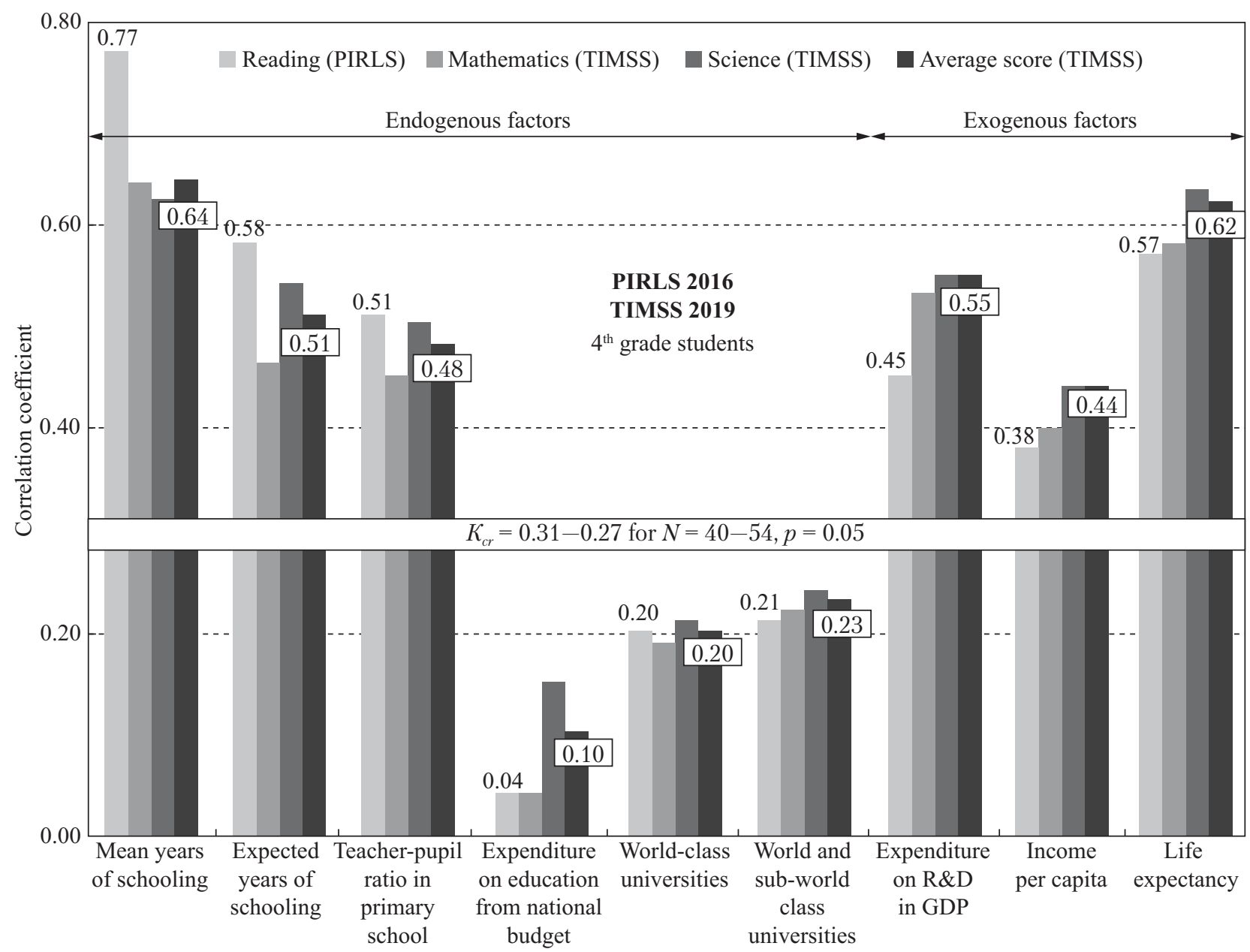

Fig. 3. The correlation (the Pearson coefficient) between the student achievement according to PIRLS 2016 ( $4^{\text {th }}$ grade) and TIMSS 2019 ( $4^{\text {th }}$ grade) and the endogenous and exogenous factors that affect the quality of education in different ways Source: calculated by the authors on the basis of $[4,5,8,12,13,17]$.

Academy of Educational Sciences of Ukraine, the Ministry of Education and Science of Ukraine, and the Verkhovna Rada Committee on Education, Science, and Innovation have been currently drafting the Law of Ukraine on Adult Education. After all, among the key competencies to build which the NUS is implemented, there is the ability to learn [44].

In order to further verify the significance and sustainability of factors influencing the quality of education, appropriate correlations have been calculated and compared for different groups of countries, namely: the world countries; the OECD members and associate members; the OECD members; the European countries; and the EU mem- ber states, for subject-averaged results of PISA 2018. Table 4 shows the ranks of the influence of each factor for these groups of countries and their group-averaged correlation coefficients.

Table 4 shows that in these cases, only the endogenous mean years of schooling and the exogenous expenditure on $\mathrm{R} \& \mathrm{D}$ are ranked first in these five groups of countries (two and three first places, respectively).

Given Fig. 1, Table 4 allows us to model the effect of each factors of influence in the descending order, in terms of promoting the quality of school education, based on the most representative PISA 2018 survey (Fig. 4). 


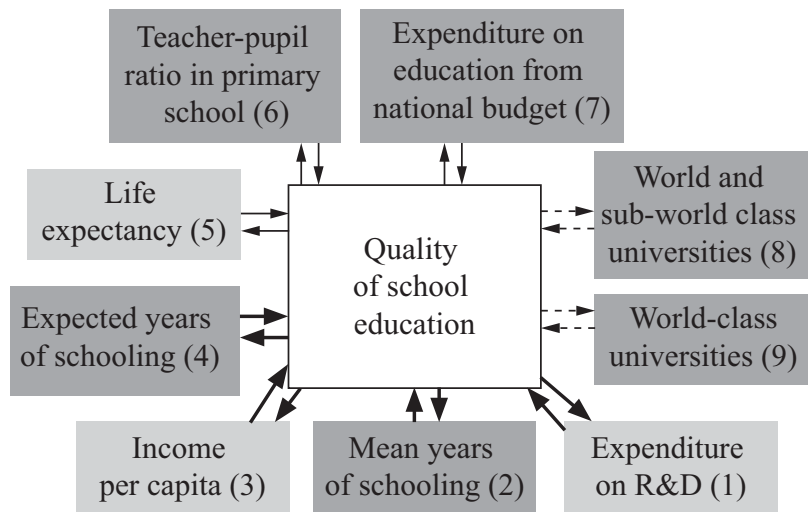

Given Table 4 and Fig. 4, we have noted the unexpectedly modest, albeit positive, role of the share of expenditure on education from budget in GDP. This result indicates that its valid interpretation requires additional research on several sub-factors related to the financing of the educational sphere, which are beyond the scope of this research. In particular, this applies to the share of GDP, which is allocated to primary and seconda-
Fig. 4. Model of significance (impact and stability) of the endogenous (dark/gray) and the exogenous (light/gray) factors for the quality of school education according to the results of PISA 2018.

Note. The factor effect corresponds to the rank in parentheses. The dark thick arrows show a stable probable effect (correlation) of the factor; the light arrows correspond to the effect which probability is lost in some cases; the dotted arrows mean a frequent loss of the probability.

Source: prepared by the authors.

ry education, funding from all sources, the amount of funding per student. For example, in $[3,157]$ it has been stated that the effect of education funding on the quality of education depends on the economic development of the country and other factors, and that the dependence of PISA results on income per capita and expenditure on education per student is more complex than linear proportionality.

Table 4. Ranking in Terms of Magnitude and Stability of the Correlation between the Quality of School Education and the Endogenous and Exogenous Factors for Different Groups of Countries, Based on the Results of PISA 2018 Survey

\begin{tabular}{|c|c|c|c|c|c|c|c|c|}
\hline \multirow[b]{2}{*}{ Factors } & \multicolumn{5}{|c|}{ Factor rank } & \multirow[b]{2}{*}{$\begin{array}{l}\text { Total } \\
\text { ranks }\end{array}$} & \multirow[b]{2}{*}{$\begin{array}{l}\text { Total } \\
\text { score }\end{array}$} & \multirow[b]{2}{*}{$\begin{array}{l}\text { Average } \\
\text { Kpears }\end{array}$} \\
\hline & $\begin{array}{c}\text { World } \\
(76 \text { countries })\end{array}$ & $\begin{array}{c}\text { OECD and } \\
\text { associates } \\
\text { (45 countries) }\end{array}$ & $\begin{array}{c}\text { OECD } \\
(37 \text { countries })\end{array}$ & $\begin{array}{c}\text { Europe } \\
\text { (44 countries) }\end{array}$ & $\begin{array}{c}\mathrm{EU} \\
(27 \text { countries })\end{array}$ & & & \\
\hline \multicolumn{9}{|c|}{ I. Endogenous factors } \\
\hline Mean years of schooling & 3 & 1 & 1 & 6 & $3-4$ & $14-15$ & $2^{1}$ & 0.59 \\
\hline Expected years of schooling & 4 & 6 & 6 & 3 & 2 & 21 & 4 & 0.53 \\
\hline $\begin{array}{l}\text { Teacher-pupil ratio in pri- } \\
\text { mary school }\end{array}$ & 6 & 5 & 3 & $-(10)$ & $-(10)$ & 34 & 6 & 0,38 \\
\hline $\begin{array}{l}\text { Expenditure on education } \\
\text { from national budget }\end{array}$ & 8 & $-(10)$ & $-(10)$ & 5 & 5 & 38 & 7 & 0.33 \\
\hline World-class university & 9 & $-(10)$ & $-(10)$ & 7 & $-(10)$ & 46 & 9 & 0.29 \\
\hline $\begin{array}{l}\text { World and sub-world class } \\
\text { universities }\end{array}$ & 7 & $-(10)$ & $-(10)$ & 8 & $-(10)$ & 45 & 8 & 0.28 \\
\hline \multicolumn{9}{|c|}{ II. Exogenous factors } \\
\hline Expenditure on $\mathrm{R} \& \mathrm{D}$ & 1 & 3 & 4 & 1 & 1 & 10 & 1 & 0,61 \\
\hline Income per capita & 5 & 2 & 2 & 2 & $3-4$ & $14-15$ & $3^{1}$ & 0.59 \\
\hline Life expectancy & 2 & 4 & 5 & 4 & $-(10)$ & 25 & 5 & 0.52 \\
\hline
\end{tabular}

Note: The dash (-) shows the loss of probability of the corresponding correlation for a specific group of countries $\left(10^{\text {th }}\right.$ place is outside the group of factors). ${ }^{1}$ In the case of score equality, the mean years of schooling is ranked higher than income per capita, given the two first places of the former and its dominance in the TIMSS and PISA surveys (see Figs. 2 and 3) Source: calculated by the authors on the basis of $[1,2,4,12,13,17]$. 


\section{Conclusions}

1. The large global systems of reliable data on the quality of education (PISA, TIMSS, PIRLS), human development, its nature and components (UNDP Human Development Reports, ARWU) have made it possible to identify the factors that determine the quality of education.

2. To assess the quality of schooling in the key subjects (reading, mathematics, and science), the correlation coefficients (135, 15 for each factor of the 9) for different sets of countries and programs have been calculated and shown a significant effect on the quality of school education for the nine indicators related to human development and innovation-driven progress (the six endogenous factors that are directly related to the educational sphere, and the three endogenous ones that determine the context of the operation of the education sphere).

3. Out of the nine factors, only two (one endogenous and one exogenous) have been identified as those having the most significant and stable (almost equal) effect that in any of the correlations never loses its positive probability. These factors are mean years of schooling and expenditure of R\&D in the country. Therefore, these two factors are critical to ensuring and improving the quality of school education.

4. The factors influencing the quality of schooling are important for the effective implementa- tion of the concept of the New Ukrainian School. In particular, the required length of schooling allows implementing the principle of human-centeredness and competence approach in education. The necessary financial support of science in the present-day conditions (which contributes to the science-intensive, high-tech economy) creates a strong positive motivation for students to study the basic school subjects.

5. For the successful reform of the educational sphere of Ukraine, in particular on the basis of the New Ukrainian School, it is advisable to use the experience of the Organization for Economic Cooperation and Development and the European Union, including that in the sphere of lifelong learning and funding science. Also, it is necessary that the second attempt to move to 12-year general secondary education in Ukraine shall be completed.

6. At the same time, in further research it is important to find out in more detail the nature and extent of the effect of investments into education on the quality of education. It is also advisable to clarify the role of world and sub-world class universities, which has a little effect on the quality of school education, but on which the world leading countries, especially the OECD and the EU members, are focusing their efforts while developing the sphere of education and science and the innovative person.

\section{REFERENCES}

1. Programme for International Student Assessment. URL: https://en.wikipedia.org/wiki/Programme_for_International_Student_Assessment (Last accessed: 20.01.2021).

2. Schleicher, A. (2019). PISA 2018. Insights and Interpretations. URL: https://search.oecd.org/pisa/PISA\%202018\%20 Insights\%20and\%20Interpretations\%20FINAL\%20PDF.pdf (Last accessed: 20.01.2021).

3. Mazorchuk, M., Vakulenko, T., Tereshhenko, V., Bychko, G., ..., Kuznyeczova, Yu. (2019). National Report on the Results of the International Survey on the Quality of Education PISA-2018. Kyiv. URL: https://testportal.gov.ua/wp-content/ uploads/2019/12/PISA_2018_Report_UKR.pdf (Last accessed: 20.01.2021) [in Ukrainian].

4. Human Development Report 2020. The next frontier: Human development and the Anthropocene. URL: http://www. hdr.undp.org/sites/default/files/hdr2020.pdf (Last accessed: 20.01.2021).

5. Mullis, I. V. S., Martin, M. O., Foy, P., Kelly, D. L., Fishbein, B. (2020). TIMSS 2019 International Results in Mathematics and Science. Retrieved from Boston College, TIMSS \& PIRLS International Study Center website: https://timssandpirls.bc.edu/timss2019/international-results/ (Last accessed: 20.01.2021).

6. Trends in International Mathematics and Science Study. URL: https://en.wikipedia.org/wiki/Trends_in_International_Mathematics_and_Science_Study (Last accessed: 20.01.2021). 
7. Mullis, I. V. S., Martin, M. O., Foy, P., Hooper, M. (2017). PIRLS 2016 International Results in Reading. Retrieved from Boston College, TIMSS \& PIRLS International Study Center website: http://timssandpirls.bc.edu/pirls2016/international-results/ (Last accessed: 20.01.2021).

8. Mullis, I. V. S., Martin, M. O., Foy, P., Hooper, M. (2017). Student Achievement Overview. URL: http://timssandpirls. bc.edu/pirls2016/international-results/pirls/student-achievement/ (Last accessed: 20.01.2021).

9. OECD. URL: https://en.wikipedia.org/wiki/OECD (Last accessed: 20.01.2021).

10. TIMSS. URL: https://ru.wikipedia.org/wiki/TIMSS (Last accessed: 20.01.2021).

11. List of research universities in the United States. URL: https://en.wikipedia.org/wiki/List_of_research_universities_ in_the_United_States (Last accessed: 20.01.2021).

12. Human Development Indices and Indicators. 2018 Statistical Update. URL: http://www.hdr.undp.org/sites/default/ files/2018_human_development_statistical_update.pdf(Last accessed: 20.01.2021).

13. Human Development Report 2016. Human Development for Everyone. URL: http://www.hdr.undp.org/sites/default/ files/2016_human_development_report.pdf (Last accessed: 20.01.2021).

14. Human Development Report 2010. The Real Wealth of Nations: Pathways to Human Development. URL: http://www. hdr.undp.org/sites/default/files/reports/270/hdr_2010_en_complete_reprint.pdf (Last accessed: 20.01.2021).

15. Human Development Report. URL: https://en.wikipedia.org/wiki/Human_Development_Report (Last accessed: 20.01.2021).

16. Academic Ranking of World Universities. URL: http://www.shanghairanking.com/index.html (Last accessed: 20.01.2021).

17. ShanghaiRanking's Academic Ranking of World Universities 2020. URL: http://www.shanghairanking.com/ARWU2020. html (Last accessed: 20.01.2021).

18. ShanghaiRanking's Global Ranking of Academic Subjects 2020 Press Release. URL: http://www.shanghairanking.com/ ShanghaiRankings-Global-Ranking-of-Academic-Subjects-2020-Press-Release.html (Last accessed: 20.01.2021).

19. Salmi, J. (2009). Establishing world-class universities. Moscow [in Russian].

20. Slyusarenko, O. M. (2015). Development of the highest university potential in the conditions of globalization: monograph. Kyiv [in Ukrainian].

21. Lugovyi, V., Sliusarenko, O., Talanova, Z. (2020). Monitoring, motivation, mobilization for the competitiveness of Ukrainian universities: Mechanisms of realization. Herald of the National Academy of Educational Sciences of Ukraine, 2(2). https://doi.org/10.37472/2707-305X-2020-2-2-13-1 (Last accessed: 20.01.2021) [in Ukrainian].

22. On approval of the list of world rankings of universities to determine a special category of foreigners and stateless persons applying for employment in Ukraine: Ordinance of the Cabinet Ministers of Ukraine of 14.04.2018. No 154. URL: http:// zakon2.rada.gov.ua/laws/show/154-2018-\%D1\%80 (Last accessed: 20.01.2021).

23. Kremen, V. G. (2010). Speech at the parliamentary hearings on June 9, 2010. Introduction of 12-year general secondary education in Ukraine: problems and ways to overcome them. URL: http://static.rada.gov.ua/zakon/skl6/11session/par_ sl/sl0906110.htm (Last accessed: 20.01.2021) [in Ukrainian].

24. On modification of legislative acts concerning general secondary and preschool education in relation to the organization of educational process: Law of Ukraine of 06.07.2010 No 2442-VI. URL: https://zakon.rada.gov.ua/laws/show/244217\#Text (Last accessed: 20.01.2021).

25. On general secondary education: Law of Ukraine of 13.05.1999 No 651-XIV. URL: https://zakon.rada.gov.ua/laws/ show/651-14\#Text (Last accessed: 20.01.2021).

26. National doctrine of education development: approved by the Decree of the President of Ukraine 17.04.2002. URL: https://zakon.rada.gov.ua/laws/show/347/2002\#Text (Last accessed: 20.01.2021).

27. Kremen, V. G. (2009). Philosophy of anthropocentrism in the strategies of educational sphere. Kyiv [in Ukrainian].

28. Kremen, V. G., Ilin V. V. (2012). Synergetics in education: context of anthropocentrism. Kyiv [in Ukrainian].

29. Hrynevych, L. M., Morze, N. V., Boiko, M. A. (2020). Scientific education as a basis for the formation of innovative competence in the context of digital transformation of society. Information Technologies and Learning Tools. 77 (3), 1-26. https://doi.org/10.33407/itlt.v77i3.3980. (Last accessed: 20.01.2021) [in Ukrainian].

30. Hrynevych, L. M. (2013). Introductory remarks and report at the parliamentary hearings on February 27, 2013. On legislative support for the development of higher education in Ukraine: materials to parliament's hearings in the Verkhovna Rada of Ukraine on February 27, 2013. Kyiv. P. 3-5, 11-16 [in Ukrainian].

31. On higher education: Law of Ukraine of 01.07.2014 No 1556-VII. URL: https://zakon.rada.gov.ua/laws/show/155618\#Text (Last accessed: 20.01.2021).

32. Lugovyi, V., Talanova, Zh. (2018). Principles of system organization of adult education space. Conceptual principles of adult education development: world experience, Ukrainian realities and prospects: a collection of scientific articles. Kyiv. P. 12-21 [in Ukrainian]. 
33. European education area. URL: https://www.europarl.europa.eu/RegData/etudes/ATAG/2020/646205/EPRS_ ATA(2020)646205_EN.pdf (Last accessed: 20.01.2021).

34. On education: Law of Ukraine of 05.09.2017 No 2145-VIII. URL: https://zakon.rada.gov.ua/laws/show/2145-19\#Text (Last accessed: 20.01.2021).

35. On complete general secondary education: Law of Ukraine of 20.01.2020 No 463-IX. URL: https://zakon.rada.gov.ua/ laws/show/463-20\#Text (Last accessed: 20.01.2021).

36. On professional pre-higher education: Law of Ukraine of 06.06.2019 No 2745-VIII. URL: https://zakon.rada.gov.ua/ laws/show/2745-19\#Text (Last accessed: 20.01.2021).

37. Hrynevych, L. M. (2015). Co-report at the parliamentary hearings on December 9, 2015. Legal support of education reform in Ukraine: materials to parliament's hearings in the Verkhovna Rada of Ukraine December 9, 2015. Kyiv: Parliamentary publishing house. P. 13-18 [in Ukrainian].

38. Co-report of the First Vice-President of the National Academy of Pedagogical Sciences of Ukraine V. I. Lugovyi (2015). Legal support of education reform in Ukraine: materials to parliament's hearings in the Verkhovna Rada of Ukraine December 9, 2015. Kyiv: Parliamentary publishing house. P. 18-22 [in Ukrainian].

39. Grynevych, L., Elkin, O., Kalashnikova, S., Kobernyk, I., ..., Shyyan, R. (2016). New Ukrainian School. Conceptual principles of secondary school reform. Kyiv. URL: https://mon.gov.ua/storage/app/media/zagalna\%20serednya/nova-ukrainska-shkola-compressed.pdf (Last accessed: 20.01.2021) [in Ukrainian].

40. Hrynevych, L. M. (2016). Report at the parliamentary hearings on November 16, 2016. On the state and problems of financing education and science: materials to parliament's hearings in the Verkhovna Rada of Ukraine 16 November, 2016. Kyiv: Parliamentary publishing house. P. 7-14 [in Ukrainian].

41. Spivakovsky, O. V. (2016). Co-report at the parliamentary hearings on November 16, 2016. On the state and problems of financing education and science: materials to parliament's hearings in the Verkhovna Rada of Ukraine 16 November, 2016. Kyiv: Parliamentary publishing house. P. 14-21 [in Ukrainian].

42. Kremen, V. G. (2016). Speech at the parliamentary hearings on November 16, 2016. On the state and problems of financing education and science: materials to parliament's hearings in the Verkhovna Rada of Ukraine 16 November, 2016. Kyiv: Parliamentary publishing house. P. 53-55 [in Ukrainian].

43. International Standard Classification of Education. ISCED 2011 / UNESCO. URL: http://uis.unesco.org/sites/default/files/documents/international-standard-classification-of-education-isced-2011-en.pdf (Last accessed: 20.01.2021).

44. The concept of implementing the state policy in the field of reforming general secondary education "New Ukrainian School" for the period up to 2029: Ordinance of the Cabinet Ministers of Ukraine of 14.12.2016 No 988-p. URL: https:// zakon.rada.gov.ua/laws/show/988-2016-\%D1\%80\#Text (Last accessed: 20.01.2021).

45. Program of joint activities of the Ministry of Education and Science of Ukraine and the National Academy of Pedagogical Sciences of Ukraine for 2017-2020: signed by Hrynevych, L., Kremen, V. 20.02.2017. URL: http://naps.gov.ua/ua/ activities/research/mon/ (Last accessed: 20.01.2021).

46. Sustainable development goals: Ukraine: national report 2017. Kyiv. P. 32-37. URL: http://un.org.ua/images/SDGs_ NationalReportUA_Web_1.pdf (Last accessed: 20.01.2021) [in Ukrainian].

47. Hrynevych, L. M. (2018). Co-report at the parliamentary hearings on March 21, 2018. National Innovation System: Status and Legislative Support of Development: materials to parliament's hearings in the Verkhovna Rada of Ukraine 21 March, 2018. Kyiv: Parliamentary publishing house. P. 7-11, 46-47 [in Ukrainian].

48. Kremen, V. G. (2018). Speech at the parliamentary hearings on March 21, 2018. National Innovation System: Status and Legislative Support of Development: materials to parliament's hearings in the Verkhovna Rada of Ukraine 21 March, 2018. Kyiv: Parliamentary publishing house. P. 37-38 [in Ukrainian].

49. Hrynevych, L. M. (2019). Report at the parliamentary hearings on April 10, 2019. Balanced development of human capital in Ukraine: tasks of education and science: materials to parliament's hearings in the Verkhovna Rada of Ukraine 10 April, 2019. Kyiv: Parliamentary publishing house. P. 6-14 [in Ukrainian].

50. Kremen, V. G. (2019). Speech at the parliamentary hearings on April 10, 2019. Balanced development of human capital in Ukraine: tasks of education and science: URL: https://static.rada.gov.ua/zakon/sk18/10session/par_sl/sl1004119.htm (Last accessed: 20.01.2021) [in Ukrainian].

51. Kremen, V., Liashenko, O., \& Lokshyna, O. (2020). General secondary education of Ukraine in the context of education in the European countries: Duration and structure. Herald of the National Academy of Educational Sciences of Ukraine, 2(2). https://doi.org/10.37472/2707-305X-2020-2-2-14-1 (Last accessed: 20.01.2021) [in Ukrainian].

52. Avshenyuk, N.M., Anishhenko, O.V., Artyushyna, M.V., Ball, G.O., ..., Bykov, V.Yu. (2016). National report on the state and prospects of education development in Ukraine. Kyiv [in Ukrainian]. 
53. Lugovyi, V. I., Talanova, Zh. V. (2016). Objective and subjective evaluation of the quality of education: world experience for Ukraine. Pedagogics and psychology. Newsletter of the NAPN of Ukraine, 4, 32-40 [in Ukrainian].

54. Vasilieva, D. V., Golovko, M. V., Zhuk, Y. O., Kozlenko, O. G., .., Novoselova, V. I. (2020). PISA-2018 lessons: methodical recommendations. Kyiv. URL: https://nus.org.ua/wp-content/uploads/2020/03/pisa.pdf(Last accessed: 12.10.2021) [in Ukrainian].

55. Godefroid, J. (2004). What is psychology: in 2 vols. V. 2. P. 308. URL: https://alleng.org/d/psy/psy040.htm (Last accessed: 20.01.2021) [in Russian].

56. Horoneskul, M. (2009). Tables of functions and critical distribution points. Sections: Probability Theory, Mathematical statistics, Mathematical methods in psychology]. Kharkiv. URL: http://repositsc.nuczu.edu.ua/bitstream/123456789/ 1530/1/Tablici.pdf (Last accessed: 20.01.2021) [in Ukrainian].

57. Lugovyi, V. I., Talanova, Zh. V. (2013). Complexity and autonomy correlation in education. Pedagogics and psychology. Newsletter of the NAPN of Ukraine, 4, 50-58 [in Ukrainian].

Received 17.02.2021

Revised 21.07.2021

Accepted 21.07.2021

В.Г. Кремень ${ }^{1,2}$ (https://orcid.org/0000-0001-5459-1318),

Л.М. Гриневич ${ }^{3}$ (https://orcid.org/0000-0002-5818-8259),

B.I. Луговий ${ }^{1,4}$ (https://orcid.org/0000-0003-1650-066X),

Ж.В. Таланова ${ }^{4,5}$ (https://orcid.org/0000-0003-4007-2677)

${ }^{1}$ Президія Національної академії педагогічних наук України,

вул. Січових Стрільців, 52-а, Київ, 04053, Україна,

+380 44481 3701, president@naps.gov.ua

${ }^{2}$ Президія Національної академії наук України,

вул. Володимирська, 54, Київ, 01030, Україна,

+380 44239 6444, prez@nas.gov.ua

${ }^{3}$ Київський університет імені Бориса Грінченка, вул. Бульварно-Кудрявська, 18/2, Київ, 04053, Україна,

+380 44272 1902, kubg@kubg.edu.ua

${ }^{4}$ Інститут вищої освіти Національної академії педагогічних наук України,

вул. Бастіонна, 9, Київ, 01014, Україна,

+380442866804, ihed@ukr.net

${ }^{5}$ Національний Еразмус+ Офіс в Україні, вул. Бастіонна, 9, Київ, 01014, Україна,

+380442866668, office@erasmusplus.org.ua

\section{ЯКІСТЬ ОСВІТИ ТА ІННОВАЦІЙНИЙ}

РОЗВИТОК: НОВА УКРАЇНСЬКА ШКОЛА

В КОНТЕКСТІ ГЛОБАЛЬНИХ ТЕНДЕНЦІЙ

Вступ. Прискорення прогресу людства зумовлене зростанням ролі інновацій, що потребує формування ефективного суб’єкта їх здійснення та підтримки - інноваційної людини, за формування якої відповідальна сфера освіти, особливо початкова та середня освітні ланки. Реформа «Нова українська школа» (НУШ), яка впроваджується з 2016 р., має адекватно спрямовуватися з огляду на сучасні виклики й тенденції.

Проблематика. Важливою в цьому контексті є ідентифікація ключових внутрішньосистемних і контекстуальних факторів впливу на якість шкільної освіти, насамперед з читання, математики, природничих наук, задля розвитку інноваційної людини.

Мета. 3'ясування ендогенних та екзогенних чинників ефективного впливу на освітню якість для оптимізації реалізації НУШ у сучасних умовах.

Матеріали й методи. Використано багатофакторний системний аналіз, зокрема статистичний, кореляційний, порівняльний, метод великих баз нових глобальних даних щодо людського розвитку, міжнародного оцінювання якості 
початкової і базової середньої освіти, розвитку світової наукової й університетської сфер та особливостей впровадження НУШ в Україні.

Результати. З'ясовано глобальні вірогідні зв'язки між якістю шкільної освіти та факторами внутрішньо-освітянського та зовнішньо-контекстуального впливу на якість освіти. 3-поміж розглянутих дев'яти чинників якості освіти школярів з читання, математики і природничих наук, особливо впливовими (резонансними) і стійкими виявилися ендогенна фактична тривалість освіти та екзогенна частка ВВП, що спрямовується на наукову сферу. При цьому впливовість зазначеної частки ВВП більша, ніж тривалості освіти. Обгрунтовано рекомендації щодо підвищення ефективності НУШ.

Висновки. Підвищити результативність реформування шкільної освіти, зокрема на засадах НУШ, можна шляхом урахування детерміністичної дії на якість освіти низки ендо- і екзогенних факторів впливу.

Ключові слова: інноваційна людина, якість освіти, ендо- і екзогенні фактори, нова українська школа. 